\title{
The Na/K-ATPase as an Amplifier for Oxidant Signals: Brief Historical Review and Possible Implications
}

\author{
Alexis D Jacob and Joseph I Shapiro* \\ Department of Surgery, University of Texas at Southwestern School of Medicine and Department of Medicine, Marshall University School of Medicine, USA
}

Our laboratories have focused their efforts over the past 20 years on elucidating the role of the sodium potassium adenosine triphosphatase $(\mathrm{Na} / \mathrm{K}-\mathrm{ATPase})$ in the cardiovascular disease associate with renal failure. Before I briefly summarize some of our insights, let me first reassure the reader that we understand that this is not a novel topic. In fact, one could argue that the $\mathrm{Na} / \mathrm{K}$-ATPase has been the most (or certainly one of the most) studied protein(s) in biomedical science since its discovery by Jens Skou in the late 1950s. Moreover, the endogenous ligands of this protein, referred to historically as " $3{ }^{\text {rd }}$ factor", digitalis like substances and more recently cardiotonic steroids have been studied by a virtual who's who of nephrology including Hugh de Wardner, Robert Schrier, Vardaman Buckalew, and Neal Bricker as well as other scientific luminaries such as Mordecai Blaustein, John Hamlyn and Alexei Bagrov [1].

The concept that these workers developed was based on the critically important pumping function of the $\mathrm{Na} / \mathrm{K}$-ATPase which, in mammalian systems, extrudes $3 \mathrm{Na}$ molecules from the intracellular milieu and brings $2 \mathrm{~K}$ molecules into the cytosol, both actions working against established concentration gradients. The Post-Albers model of the sodium pump involves cycling between E1 and E2 states to allow for energy dependent pumping of $\mathrm{Na}$ and $\mathrm{K}$ against their concentration gradients [2]. Up until the late 1990s, all signaling function attributed to the pump involved either augmented or inhibited pumping function producing changes in cytosolic $\mathrm{Na}$ and $\mathrm{K}$ to initiate the postulated signal cascade. A detailed description of the shortcomings of this ionic model for sodium pump signaling is beyond the scope of this editorial but is discussed in several recent reviews [1-4]. While some effects of cardiotonic steroids may, in fact, be mediated through alteration of the pumping function of the $\mathrm{Na} / \mathrm{K}$-ATPase, a different role of this protein probably explains quite bit more.

In the late 1990s, Dr. Zijian Xie and collaborators from our laboratories uncovered evidence supporting a scaffolding function for the $\mathrm{Na} / \mathrm{K}$-ATPase $[5,6]$. Specifically, it was observed that in higher animals, a portion of the $\mathrm{N}$ domain of the alphal subunit contained a sequence which bound the kinase domain of sarcoma related kinase (Src) $[7,8]$. When the conformation of the Na/K-ATPase was altered by binding a cardiotonic steroid or oxidation (vida infra), Src was able to modify the epithelial growth factor receptor (EGFR) and trigger a signal cascade which leads to the generation of reactive oxygen species (ROS) and widespread downstream effects ranging from increases in cytosolic calcium to changes in gene transcription [9]. Additional work from our laboratories established that these ROS fed back to the alphal subunit with specific carbonylation sites, allowing the $\mathrm{Na} / \mathrm{K}$-ATPase signal cascade to function as a feed forward amplifier whose signal appears to be terminated by endocytosis. This endocytosis of the basolateral $\mathrm{Na} / \mathrm{K}$-ATPase in renal proximal tubular cells appears to be coordinated with a redistribution of the apical sodium proton antiporter (isoform 3, NHE3) allowing for a meaningful decrease in net sodium reabsorption by the kidney [10-14]. However, additional work speaks to a role for the $\mathrm{Na} / \mathrm{K}$-ATPase as a promiscuous amplifier of oxidant signals, potentially relevant to a number of cardiovascular conditions including renal fibrosis and hypertension, uremic cardiomyopathy and obesity/ metabolic syndrome [15-21].

The concept that emerges from this body of work is the $\mathrm{Na} / \mathrm{K}$-ATPase signal cascade as an amplifier system with the endogenous cardiotonic steroids serving as a biological rheostat to this amplifier. Although not all hormone and cytokines signal via oxidants, many do, and the $\mathrm{Na}$ / K-ATPase signal cascade essentially amplifies the signal produced by those that do. That stated, if this scenario is correct, it offers a novel and potentially safe targets for a number of biomedical conditions. In some cases, stimulating this oxidant amplification in target tissues might be appropriate (e.g., organ differentiation and development in premature infants, muscle hypertrophy in post-traumatic rehabilitation) whereas blocking this pathway could potentially ameliorate maladaptive growth and scarring (e.g., cardiomyopathy associated with renal failure, scleroderma). To date, some agonists of the $\mathrm{Na} / \mathrm{K}$-ATPase signal cascade have been identified as have some antagonists. We have also specifically developed classes of peptides which serve as signal complex disrupters as well as signal terminators [17,20,22-25]. It is our hope and expectation that pharmacological agents useful in the clinic will be developed from Professor Xie's insights which have reinvigorated the study of this important system.

\section{References}

1. Dial L, Liu J, Shapiro Jl (2014) Cardiotonic steroids in adaptation to dietary salt intake. Curr Clin Pharmacol 9: 298-309.

2. Bagrov AY, Shapiro JI, Fedorova OV (2009) Endogenous cardiotonic steroids: physiology, pharmacology, and novel therapeutic targets. Pharmacol Rev 61 9-38.

3. Assaly R, Olson D, Hammersley J, Fan PS, Liu J, et al. (2001) Initial evidence of endothelial cell apoptosis as a mechanism of systemic capillary leak syndrome. Chest 120: 1301-1308.

4. Bagrov AY, Shapiro JI (2008) Endogenous digitalis: pathophysiologic roles and therapeutic applications. Nat Clin Pract Nephrol 4: 378-392.

5. Liu J, Tian J, Haas M, Shapiro JI, Askari A, et al. (2000) Ouabain interaction with cardiac $\mathrm{Na}+/ \mathrm{K}+-\mathrm{ATPase}$ initiates signal cascades independent of changes in intracellular $\mathrm{Na}+$ and $\mathrm{Ca} 2+$ concentrations. J Biol Chem 275: 27838-27844.

6. Xie Z, Kometiani P, Liu J, Li J, Shapiro JI, et al. (1999) Intracellular reactive oxygen species mediate the linkage of $\mathrm{Na}+/ \mathrm{K}+-\mathrm{ATP}$ ase to hypertrophy and its marker genes in cardiac myocytes. J Biol Chem 274: 19323-19328.

7. Haas M, Askari A, Xie Z (2000) Involvement of Src and epidermal growth facto

${ }^{*}$ Corresponding author: Joseph I. Shapiro, M.D, Dean, Joan C. Edwards School of Medicine, 1600 Medical Center Drive, Suite 3408, Huntington, WV 25701 304.691.1700, USA, Tel: 304.691.1726; E-mail: shapiroj@marshall.edu

Received October 28, 2015; Accepted October 30, 2015; Published November 06, 2015

Citation: Jacob AD, Shapiro $\mathrm{JI}$ (2015) The Na/K-ATPase as an Amplifier for Oxidant Signals: Brief Historical Review and Possible Implications J Hypertens 5 : e115. doi:10.4172/2167-1095.1000e115

Copyright: $\odot 2014$ Jacob AD, et al. This is an open-access article distributed unde the terms of the Creative Commons Attribution License, which permits unrestricted use, distribution, and reproduction in any medium, provided the original author and source are credited. 
Citation: Jacob AD, Shapiro Jl (2015) The Na/K-ATPase as an Amplifier for Oxidant Signals: Brief Historical Review and Possible Implications J Hypertens 5: e115. doi:10.4172/2167-1095.1000e115

Page 2 of 2

receptor in the signal-transducing function of $\mathrm{Na}+/ \mathrm{K}+-\mathrm{ATPase} . \mathrm{J}$ Biol Chem 275: $27832-27837$

8. Haas M, Wang H, Tian J, Xie Z (2002) Src-mediated inter-receptor cross-talk between the $\mathrm{Na}+/ \mathrm{K}+-\mathrm{ATPase}$ and the epidermal growth factor receptor relays the signal from ouabain to mitogen-activated protein kinases. J Biol Chem 277 : 18694-18702.

9. Wang H, Haas M, Liang M, Cai T, Tian J, et al. (2004) Ouabain assembles signaling cascades through the caveolar $\mathrm{Na}+/ \mathrm{K}+-\mathrm{ATPase}$. J Biol Chem 279: 17250-17259.

10. Cai H, Wu L, Qu W, Malhotra D, Xie Z, et al. (2008) Regulation of apical NHE3 trafficking by ouabain-induced activation of the basolateral $\mathrm{Na}+-\mathrm{K}+-\mathrm{ATPase}$ receptor complex. Am J Physiol Cell Physiol 294: C555-563.

11. Liu J, Kesiry R, Periyasamy SM, Malhotra D, Xie Z, et al. (2004) Ouabain induces endocytosis of plasmalemmal Na/K-ATPase in LLC-PK1 cells by a clathrin-dependent mechanism. Kidney Int 66: 227-241.

12. Liu J, Liang M, Liu L, Malhotra D, Xie Z, et al. (2005) Ouabain-induced endocytosis of the plasmalemmal Na/K-ATPase in LLC-PK1 cells requires caveolin-1. Kidney Int 67: 1844-1854.

13. Yan Y, Haller S, Shapiro A, Malhotra N, Tian J, et al. (2012) Ouabain-stimulated trafficking regulation of the $\mathrm{Na} / \mathrm{K}-\mathrm{ATPa}$ a and $\mathrm{NHE} 3$ in renal proximal tubule cells. Mol Cell Biochem 367: 175-183.

14. Yan Y, Shapiro AP, Haller S, Katragadda V, Liu L, et al. (2013) Involvement of reactive oxygen species in a feed-forward mechanism of $\mathrm{Na} / \mathrm{K}-\mathrm{ATPase}$ mediated signaling transduction. J Biol Chem 288: 34249-34258.

15. Haller ST, Kennedy DJ, Shidyak A, Budny GV, Malhotra D, et al. (2012) Monoclonal antibody against marinobufagenin reverses cardiac fibrosis in rats with chronic renal failure. Am J Hypertens 25: 690-696.

16. Kolmakova EV, Haller ST, Kennedy DJ, Isachkina AN, Budny GV, et al. (2011) Endogenous cardiotonic steroids in chronic renal failure. Nephrol Dial Transplant 26: 2912-2919.
17. Tian J, Shidyak A, Periyasamy SM, Haller S, Taleb M, et al. (2009) Spironolactone attenuates experimental uremic cardiomyopathy by antagonizing marinobufagenin. Hypertension 54: 1313-1320.

18. Kennedy DJ, Chen Y, Huang W, Viterna J, Liu J, et al. (2013) CD36 and Na/KATPase-Ît1 form a proinflammatory signaling loop in kidney. Hypertension 61 : 216-224.

19. Kennedy DJ, Elkareh J, Shidyak A, Shapiro AP, Smaili S, et al. (2008) Partial nephrectomy as a model for uremic cardiomyopathy in the mouse. Am J Physiol Renal Physiol 294: F450-454.

20. Kennedy DJ, Vetteth S, Periyasamy SM, Kanj M, Fedorova L, et al. (2006) Central role for the cardiotonic steroid marinobufagenin in the pathogenesis of experimental uremic cardiomyopathy. Hypertension 47: 488-495.

21. Sodhi K., Maxwel K., Yan Y, Liu J, Chaudhary M, et al. (2015) pNaKtide inhibits $\mathrm{Na} / \mathrm{K}$-ATPase reactive oxygen species amplification and attenuates adipogenesis. Science Advances In Press (2015).

22. El-Okdi N, Smaili S, Raju V, Shidyak A, Gupta S, et al. (2008) Effects of cardiotonic steroids on dermal collagen synthesis and wound healing. J Appl Physiol (1985) 105: 30-36.

23. Li Z, Cai T, Tian J, Xie JX, Zhao X, et al. (2009) NaKtide, a Na/K-ATPasederived peptide Src inhibitor, antagonizes ouabain-activated signal transduction in cultured cells. J Biol Chem 284: 21066-21076.

24. Li Z, Zhang Z, Xie JX, Li X, Tian J, et al. (2011) Na/K-ATPase mimetic pNaKtide peptide inhibits the growth of human cancer cells. J Biol Chem 286: 3239432403.

25. Ferrari P, Ferrandi M, Valentini G, Bianchi G (2006) Rostafuroxin: an ouabain antagonist that corrects renal and vascular $\mathrm{Na}+-\mathrm{K}+-$ ATPase alterations in ouabain and adducin-dependent hypertension. Am J Physiol Regul Integr Comp Physiol 290: R529-535. 